\title{
Do Fascismo ao Pós-Fascismo ${ }^{1}$
}

Recebido:22 -06-2019

Aprovado: 22-08-2019

Enzo Traverso ${ }^{2}$

\section{Definições}

O surgimento da direita radical é uma das mais notáveis características de nosso momento histórico. Em 2018, oito países da União Europeia (Áustria, Bélgica, Dinamarca, Finlândia, Itália, Polônia, Hungria e Eslováquia) são governados por partidos da extremadireita, nacionalistas e xenófobos. Esses partidos também polarizaram a disputa política em três das maiores nações da União Europeia: na França, a Frente Nacional perdeu as eleições presidenciais de 2017, mas alcançou extraordinários 33.9\% dos votos; na Itália, a Liga do Norte tornou-se a força hegemônica da direita ao criar um novo governo e marginalizar a Forza Italia de Silvio Berlusconi; e na Alemanha o Alternativa para a Alemanha assumiu cadeiras no Bundestag em 2017 com quase 13\% dos votos, resultado que enfraqueceu sobremaneira a Chanceler Angela Merkel e levou a União Democrática Cristã (CDU) a renovar sua coalisão com o Partido Social Democrata (SPD). A "exceção Alemã", frequentemente louvada desapareceu, e Merkel anunciou sua intenção de repensar suas políticas "generosas" em favor dos imigrantes e refugiados. Fora da União Europeia, a Rússia de Putin e alguns de seus satélites estão longe de serem os únicos bastiões do nacionalismo. Com a eleição de Donald Trump para a presidência dos Estados Unidos, o surgimento de uma direita nacionalista, populista, racista e xenófoba, tornou-se um fenômeno global. O mundo ainda não havia experimentado um similar crescimento da direita radical desde os anos de

\footnotetext{
${ }^{1}$ O presente texto compõe o capítulo 1 "From Fascism to Postfascism" do livro The New Faces of Fascism: Populism and the Far Right, publicado pela editora Verso na Inglaterra e nos Estados Unidos em 2019. Agradecemos ao autor, como também à Editora Âyiné, pela autorização da tradução que terá publicação integral da obra no Brasil em breve. Tradução do original em inglês por Monica Lúcia R. Fernandes e Rafael Alexandre Mello (IREL/UnB), com revisão de Raphael Lana Seabra (ELA/UnB), membros do Grupo de Estudos sobre Pensamento Crítico Latino-Americano (ECLA-UnB).

${ }^{2}$ Historiador italiano que atualmente é professor no Susan and Barton Winokur em Ciências Humanas na Cornell University, Estados Unidos. É autor de The Marxsists and the Jewish Question; The Jews and Germany; Undestanding the Nazi Genocide; The Origins of Nazi Violence; Fire and Blood; The European Civil War, 1914 1945 entre outros. Suas obras foram traduzidas e publicadas em diversas línguas, no Brasil teve publicado Melancolia de esquerda: Marxismo, História e Memória pela Editora Âyiné em 2018.
}

Revista de Estudos e Pesquisas sobre as Américas V.13 N.2 2019 ISSN: 1984-1639 
1930, um desenvolvimento que desperta a memória sobre o fascismo. Seu fantasma ressurgiu nos debates contemporâneos e reabriu a antiga questão da relação entre a historiografia e o uso público do passado. Reinhart Koselleck (2002, p. 20-37) nos lembra de que há uma tensão entre os fatos históricos e sua transcrição linguística: conceitos são indispensáveis para se pensar a experiência histórica, mas também podem ser usados para compreender novas experiências que estão ligadas ao passado através de uma rede de continuidade temporal. A comparação histórica que tenta estabelecer mais analogias e diferenças do que homologias e repetições surge da tensão entre história e linguagem.

Atualmente, o surgimento da direita radical traz uma ambiguidade semântica: por um lado, quase ninguém fala abertamente do fascismo - exceções notáveis ao Aurora Dourada na Grécia, o Movimento por uma Hungria Melhor (Jobbik) na Hungria e o Partido Nacional na Eslováquia - e a maioria dos observadores reconhecem as diferenças entre esses novos movimentos e os seus antepassados dos anos 1930. Por outro lado, qualquer tentativa de definir este novo fenômeno nos faz comparar com os anos do Entre Guerras. Em resumo, o conceito de fascismo parece ser inapropriado e indispensável para se compreender esta nova realidade. Portanto, chamarei o momento atual de um período de pós-fascismo. Este conceito enfatiza sua particularidade cronológica e o localiza em uma sequência histórica marcada tanto pela continuidade quanto pela transformação; certamente ele não responde a todas as questões que foram abertas, mas ele enfatiza a realidade da mudança.

Antes de tudo, é preciso não esquecer que o conceito de fascismo tem sido usado desde a Segunda Guerra Mundial e não só para definir as ditaduras militares na América Latina. Em 1959, Theodor Adorno escreveu que "a sobrevivência do Nacional Socialismo dentro da democracia" era potencialmente mais perigoso do que a "sobrevivência das tendências fascistas contra a democracia" (Adorno, 2005, p. 90). Em 1974, Pier Paolo Pasolini retratou os modelos antropológicos do capitalismo neoliberal como um "novo fascismo" o qual, quando comparado ao regime de Mussolini, parecia irremediavelmente arcaico, um tipo de "paleofascismo" (Pasolini, 2008, p.63). E mesmo em décadas mais recentes, muitos historiadores buscam associar a Itália de Berlusconi - e não sua filiação - ao fascismo clássico. Claro que havia enormes diferenças entre este regime e o fascismo histórico - o culto ao mercado em lugar do estado, das propagandas da televisão ao invés de “desfiles oceânicos" e assim por diante - mas a concepção de democracia plebiscitária de 
Berlusconi e a liderança carismática evocam fortemente o arquétipo fascista (D’Arcais, 2011, p.121-40; Gibelli, 2011).

Esta pequena digressão mostra que o fascismo não apenas foi transnacional ou transatlântico (Finchelstein, 2010), mas também trans-histórico. A memória coletiva estabelece uma ligação entre o conceito e seu uso público, que costuma excede sua dimensão puramente historiográfica. Sob esta perspectiva, o fascismo (assim como outros conceitos em nosso léxico político) poderia ser visto como um conceito trans-histórico capaz de transcender a idade que o engendrou. Afirmar que os Estados Unidos, o Reino Unido e a França são democracias, não quer dizer que se postule a identidade de seus sistemas políticos ou que eles correspondam à democracia ateniense do período de Péricles. No Século XXI, o fascismo não terá a face de Mussolini, Hitler e Franco; e nem (esperamos) terá a forma do terror totalitário. Sabemos, no entanto que há muitas formas de se destruir a democracia. As referências rotineiras às ameaças à democracia - particularmente o terrorismo islâmico - costumam retratar o inimigo como externo, mas elas se esquecem de uma lição fundamental da história do fascismo: que a democracia pode ser destruída a partir de dentro.

$\mathrm{Na}$ verdade, o fascismo é parte central de nossa consciência histórica e de nosso imaginário político, mas muitos aspectos do contexto atual complicam esta referência histórica. Entre essas novas circunstâncias, destaca-se o surgimento do terrorismo islâmico, que alguns atores políticos e comentaristas costumam chamar de "fascismo islâmico". Como a nova direita radical se assume como um bastião contra este "fascismo islâmico", a palavra fascismo é mais um obstáculo do que uma categoria de interpretação. Daí, porque o termo pós-fascismo ser mais apropriado. Sem desconsiderar seus limites evidentes, este termo nos ajuda a descrever um fenômeno em transição, um movimento ainda em transformação e ainda não cristalizado. Por esta razão o "pós fascismo" não tem o mesmo status do conceito "fascismo". O debate historiográfico sobre o fascismo ainda está em aberto, mas ele define um fenômeno cujas fronteiras cronológicas e políticas são bastante claras. Quando falamos de fascismo, não há ambiguidade sobre o que falamos, mas as novas forças da direita radical são fenômenos heterogêneos e complexos. Eles não têm as mesmas características em todos os países, inclusive os da Europa: da França para a Itália; da Grécia para a Áustria, da Hungria para a Polônia e Ucrânia, elas têm pontos em comum, mas são muito diferentes uma das outras. 
O Pós-fascismo também deve ser distinguido do neofascismo, que é uma tentativa de perpetuar e regenerar o velho fascismo. São exemplos disto, vários partidos e movimentos que surgiram na Europa Central ao longo das últimas duas décadas (Jobbik na Hungria, por exemplo) pregam abertamente uma continuidade ideológica com o fascismo histórico. O pósfascismo é algo mais: em muitos casos, ele surge de um passado fascista clássico, mas vem mudando suas formas. Muitos movimentos pertencentes a esta constelação não apelam a essas origens e se distinguem do neofascismo. De qualquer modo, eles não exibem uma continuidade ideológica com o fascismo clássico. No esforço de defini-los, não podemos ignorar o ventre fascista de onde eles surgiram, na medida em que essas são suas raízes históricas, mas também devemos levar em consideração suas metamorfoses. Eles se transformaram e tomaram um rumo cujo resultado é imprevisível. Quando tiverem se estabelecido como outra coisa, com características política e ideológica estáveis, teremos que cunhar uma nova definição. O pós-fascismo pertence a um regime particular de historicidade - começo do século XXI - o que explica seu conteúdo ideológico errático, instável e contraditório, no qual se misturam filosofias políticas antinômicas.

A Frente Nacional, movimento francês bastante conhecido, sintetiza essas transformações. É em vários aspectos uma força emblemática devido ao seu recente sucesso e sua presença na política europeia. Quando de sua fundação em 1972, era óbvio que tinha sido gestado no ventre do fascismo francês. Nas décadas seguintes ela conseguiu aglutinar várias correntes da extrema direita, nacionalistas e católicos-fundamentalistas, Poujadistas ${ }^{3}$ e Colonialistas (nostálgicos da Argélia Francesa). Provavelmente, a chave desta operação de sucesso foi a curta distância histórica que a separa Vichy ${ }^{4}$ das guerras coloniais da França. O conteúdo fascista foi capaz de juntar todos e servir como força motriz do partido no momento de sua fundação.

A Frente Nacional tinha começado a evoluir já em 1990, mas só quando Marine Le Pen tornou-se líder em 2011 que o partido começou a "mudar de pele" 5 . Seu discurso mudou, deixando de clamar seus velhos princípios políticos e ideológicos e se reposicionando mais significativamente no palco da política francesa. Preocupado com a sua reputação, a Frente

\footnotetext{
${ }^{3}$ Refere-se ao movimento surgido na França entre 1954 e 1958 liderado por Pierre Poujade, um livreiro ultrarreacionário e que contemporaneamente refere-se à demagogia (Nota das Tradutoras - N.T.)

${ }^{4}$ Trata-se da região francesa que durante a ocupação alemã na Segunda Guerra Mundial colaborou ativamente com o nazismo entre 1940 e 1944 sob o governo títere do Marechal Philippe Pétain (N.T.).

${ }^{5}$ Existe uma vasta literatura sobre a história da Frente Nacional, para uma visão geral veja Valerie Igounet, 2014.
}

Revista de Estudos e Pesquisas sobre as Américas V.13 N.2 2019 ISSN: 1984-1639 
Nacional buscou se juntar ao sistema da Quinta República, apresentando-se como uma alternativa "normal" e indolor. Claro que se opôs à União Europeia e ao establishment tradicional, mas não mais desejava parecer uma força subversiva. Diferentemente do fascismo clássico, que queria mudar tudo, a ambição da Frente Nacional é agora transformar o sistema de dentro. Pode-se argumentar que mesmo Mussolini e Hitler conquistaram o poder por caminhos legais, mas a objeção não se sustenta; a vontade deles em derrubar o Estado de Direito e varrer a democracia foi afirmada claramente.

Mais do que um legado político, a linha de descendência de Marine Le Pen na Frente Nacional tem a forma de filiação biológica: foi o pai quem entregou o poder à filha, dando claros traços dinásticos a esta passagem. Mas este partido nacionalista é agora dirigido por uma mulher, fato até então sem precedente no movimento fascista. A Frente Nacional é também marcada por tensões, as quais são mais aparentes no campo do conflito ideológico entre pai e filha e, sobretudo, entre as correntes ligadas à antiga Força Nacional e aquelas que querem transformá-la em outra coisa. A Frente Nacional começou uma metamorfose, uma mudança de linha, ainda não cristalizada; a transformação ainda está em curso.

\section{Europa}

Frente à nova ascensão da extrema-direita, seria uma ilusão perigosa encarar a União Europeia como o "remédio". Apesar de uma poderosa retórica sobre a ideia europeia, o resultado de várias décadas de políticas da União Europeia (UE) é um fracasso. O contraste entre as elites da UE e seus antecessores é convincente. É tão forte que, por reação, ficamos tentado a admirar seus pais fundadores. Não falo dos intelectuais, como Altiero Spinelli que imaginou uma Europa Federal em meio a uma terrível guerra. Penso nos arquitetos da União Européia: Konrad Adenauer, Alcide de Gasperi e Robert Schuman. Susan Watkins nos lembrou recentemente que todas essas figuras nasceram nos anos 1880, no apogeu do nacionalismo e cresceram em uma época em que se viajava em carruagens puxadas à cavalo (Watkins, 2014, p.2-25). Provavelmente eles compartilhavam uma certa concepção alemã sobre a Europa: Adenauer tinha sido prefeito de Colônia, De Gasperi tinha representado a minoria italiana no Parlamento Hapsburg, e Schuman cresceu em Strasburgo, na Alsácia alemã antes de 1914. Quando se encontraram, falavam em alemão, mas defendiam uma visão cosmopolita e multicultural da Alemanha, distante da tradição do nacionalismo Prussiano e do 
Pan-Germanismo (Judt, 2005, p.157). Tinham uma visão de Europa, que eles esboçaram tendo um destino comum em um mundo bipolar, e eles tiveram coragem na medida em que propuseram este projeto à povos que tinham saído de uma guerra civil continental. O plano de uma integração econômica - carvão e aço - ficou no desejo político. Eles conceberam um mercado comum como o primeiro passo em direção à uma unificação política, e não como um ato de submissão à interesses financeiros. Pelo bem ou pelo mal, Helmut Kohl e François Mitterrand foram os últimos a agir como estadistas. Não tinham a mesma estatura de seus antecessores, mas não eram executivos de bancos e de instituições financeiras internacionais.

A geração que os sucedeu na passagem para o Século XXI e um não tem nem visão se gabam de sua falta de ideias como sendo uma virtude pós-ideológico do pragmatismo nem coragem, na medida em que suas escolhas dependem de pesquisas de opinião. Seu exemplo é Tony Blair, o artista da mentira, do oportunismo e do carreirismo político, atualmente desacreditado em seu próprio país, mas ainda envolvido em atividades lucrativas. Um europeísta convicto - o mais pró-Europeu dos líderes ingleses do pós-guerra - ele representa uma mutação: o nascimento de uma elite política neoliberal que transcende a clivagem tradicional entre direita e esquerda. Tarik Ali chama isto de "extrema direita" (Ali, 2015). Blair serviu de modelo para François Hollande, Matteo Renzi, para os líderes do Partido Socialista Operário Espanhol (PSOE), e em certa medida, até para Angela Merkel, que governa em perfeita harmonia com o SPD. Atualmente, o neoliberalismo incorporou os herdeiros da social democracia e das correntes conservadoras cristãs.

O resultado desta mudança foi o impasse do próprio projeto europeu. Por um lado, esta falta de visão transformou a UE em uma agência encarregada de aplicar medidas exigidas pelos poderes financeiros e, por outro lado, a falta de coragem impediu qualquer avanço do processo de integração politica. Obcecados pelas pesquisas de opinião, os dirigentes da UE padecem de uma visão estratégica; são incapazes de pensar além das próximas eleições. Paralisada pela impossibilidade de retornar às antigas soberanias nacionais e resistentes a construir instituições federais, a UE criou um monstro estranho e horrível: a troika, uma entidade sem existência jurídica e política, sem legitimidade democrática e mesmo assim, detém o poder real e as regras do continente. O Fundo Monetário Internacional (FMI), o Banco Central Europeu (BCE) e a Comissão Européia determinam as políticas de todos os governos nacionais, avaliam sua implantação e decidem sobre os ajustes compulsórios. Podem inclusive mudar o próprio executivo, como ocorreu na Itália no final de 2011 e no 
verão de 2018. No primeiro caso, Mario Monti, o homem de confiança do BCE e do Goldman Sachs, destituiu Berlusconi; no segundo caso, o Presidente Sergio Mattarella recusou-se a nomear o Ministro da Economia de um governo apoiado pela maioria parlamentar porque muitos jornais o acusavam de "eurocético", isto é, hostil à moeda da UE. Monti, um líder técnico não eleito, aplicou o receituário à troika. Em 2018, Paolo Savona foi substituído por Giovanni Tria, um economista que a troika considerava mais confiável, em troca de uma série de concessões às demandas xenofóbicas e autoritárias da Liga do Norte. O direito a decidir sobre a vida e a morte de seres humanos - o direito que distingue a soberania clássica - é exatamente o direito que a troika impôs aos gregos durante a crise da Grécia, ao ameaçar de morte e asfixia todo o país. Quando a troika não tem interesses específicos para defender, a União Europeia não existe e se quebra: por exemplo, para enfrentar a crise dos refugiados, cada país quer fechar suas fronteiras. Em circunstâncias como essas, os políticos xenófobos não são mais incompatíveis com a governança da UE.

Este superpoder não emana de nenhum parlamento ou da soberania popular, uma vez que o FMI não faz parte da UE, o "Euro Grupo" é um ajuntamento informal de ministros das finanças, e o BCE (de acordo com seu próprio estatuto) é uma instituição independente. Como muitos analistas observam, a troika é um Estado de Exceção. No entanto, este Estado de Exceção, não tem muitas semelhanças com as ditaduras do passado, pois de acordo com a teoria política clássica, expressavam a autonomia do político. Na situação atual, este Estado de Exceção não é transitório, mas é seu próprio modo de funcionar - a exceção tornou-se a regra - e significa a completa submissão do político ao financeiro ${ }^{6}$. Em suma, é um Estado de Exceção que determina um tipo de ditadura financeira, um Leviatã neoliberal. A troika fixa as regras, transmite-as à diferentes estados da UE e controla sua aplicação. Em síntese, é o “ordoliberalismo" de Wolfgang Schäuble: não é o capitalismo submetido às regras políticas, mas um capitalismo financeiro que dita suas próprias regras. Os dirigentes podem agir como comissários, no sentido Schmittiano, mas o Nomos (um tipo de lei existencial) que eles incorporam e para o qual todas as regras jurídicas estão submetidas é econômico e financeiro, não político. Portanto, a contradição constitutiva de nossas democracias modernas em que uma racionalidade jurídico-política coexiste com uma racionalidade econômico-gerencial finalmente encontrou uma solução ao substituir o corpo político democracia - por uma técnica

\footnotetext{
${ }^{6}$ Sobre a "autonomia do politico" veja Carl Schmitt, 2007.

Revista de Estudos e Pesquisas sobre as Américas V.13 N.2 2019 ISSN: 1984-1639
} 
de governo ${ }^{7}$. Em outras palavras, governo foi substituído por governança, o resultado de uma financeirização da política que transformou o estado em uma ferramenta que incorpora e dissemina a razão neoliberal (Brown, 2015, p.70-78). Quem poderia personificar um Estado de exceção financeiro melhor do que Jean-Claude Juncker? Por vinte anos ele dirigiu o Grãoducado de Luxemburgo e o transformou na pátria da evasão fiscal do capitalismo. A definição de estado que Marx criou no século dezenove - um comitê para administrar os negócios comuns de toda a burguesia - finalmente foi incorporada com perfeição pela UE.

Se a UE não é capaz de mudar o curso depois do trauma do Brexit, pode-se perguntar como ela sobreviverá - e se ela merece isto. A UE não é, atualmente, uma barreira para o crescimento da extrema direita, mas o combustível para ela. Com efeito, o desenrolar da UE poderá ter um efeito imprevisível na forma como esses movimentos se desenvolvem. Se a UE estivesse por se romper, detonando uma crise econômica, a extrema direita poderia muito bem radicalizar: o pós-fascismo tomaria então a trilha do neofascismo. E este processo, poderia se espalhar de país para país num efeito dominó. Ninguém pode imaginar como controlar este cenário aterrador que só reforçaria o caráter instável da direita pós-fascista.

Mas ainda não chegamos a este ponto. Hoje, a força dominante da economia global o capital financeiro - não aposta nesses movimentos, seja na Marine Le Pen na França ou os neofascistas em outros países. De fato, o capital financeiro apoia os pilares políticos da EU, ou seja, os partidos do "extremo centro". Essas forças se opuseram ao Brexit, assim como Wall Street apoiou Hillary Clinton nas eleições americanas. O cenário acima descrito, onde a direita radical chegaria ao poder e a UE se desintegraria, teria que envolver todo um bloco social e político de todo o continente. Em um contexto de caos prolongado, tudo é possível. Foi o que aconteceu na Alemanha entre 1930 e 1933, quando os nazistas ao criar um movimento de "plebeus enraivecidos" tornaram-se o interlocutor inevitável do grande negócio, as elites financeiras e industriais, e depois o exército. No período do entre guerra, o fascismo proclamava ser uma opção contra o bolchevismo. Diferentemente dos anos 1930, no entanto, a atual crise europeia não indica o caminho (pelo menos em termos previsíveis) para uma solução à esquerda. A ausência de uma alternativa crível tem consequências muito contraditórias.

Um dos pilares fundamentais do fascismo clássico foi o anticomunismo. (Mussolini definiu seu movimento como sendo uma "revolução contra revolução"). Não há nada

\footnotetext{
${ }^{7}$ Esta distinção é conceitualizada e analisada por Agamben, 2011.

Revista de Estudos e Pesquisas sobre as Américas V.13 N.2 2019 ISSN: 1984-1639
} 
comparável na imaginação pós-fascista, que não é assombrada por figuras Jungerianas de milicianos com corpos metálicos esculpidos nas trincheiras. Conhecem-se apenas corpos esculpidos em academias esportivas. O comunismo e a esquerda não são mais seus inimigos mortais e principais. Na paisagem mental do pós-fascismo, o terrorista islâmico que substituiu o bolchevique não trabalha nas fábricas, mas sim se esconde nos subúrbios ocupados por imigrantes pós-coloniais. Por isso numa perspectiva histórica, o pós-fascismo poderia ser visto como sendo o resultado da derrota das revoluções do século XX: após o colapso do comunismo e dos partidos socialdemocratas abraçarem a governabilidade neoliberal, a direita radical está se tornando, em muitos países, a força mais influente de oposição ao "sistema", mesmo que não assuma uma face subversiva e evite competir com a esquerda radical.

No entanto, tal posição não é apenas vantajosa à direita radical. Nos anos de 1930, foi o anticomunismo empurrou as elites europeias a aceitar Hitler, Mussolini e Franco. Vários historiadores afirmam que esses ditadores se beneficiaram não apenas de "erros de cálculo" dos governantes e dos partidos conservadores tradicionais, mas não há dúvida de que sem Revolução Russa e da depressão global, as elites econômica, militar e política alemãs frente ao colapso da República de Weimar não teriam permitido Hitler tomar o poder. Hoje, os interesses das elites econômicas são muito melhor representados pela União Europeia do que pela direita radical. A segunda poderia se tornar um interlocutor de confiança e uma liderança potencial só na hipótese do colapso do euro, o que levaria o continente ao caos e instabilidade. Desafortunadamente, esta possibilidade não é impossível. Nossas elites econômicas lembram os "sonâmbulos" às vésperas de 1914, os responsáveis do "show europeu" que mergulharam na catástrofe completamente alienados do que estava ocorrendo (Clark, 2012).

A extrema direita tem diferentes faces em diferentes países e não pode ser combatida na Grécia da mesma forma que na Alemanha, França ou Itália. Entretanto, podemos ter vários indicativos a partir do exemplo francês, um país cujo sistema político amplifica enormemente a extrema direita todas as vezes que há eleições presidenciais. Depois do terremoto da disputa de 2002, em que Jean Marie Le Pen chegou ao segundo turno pela primeira vez, a Frente Nacional foi capaz de influenciar a agenda política nacional. Quinze anos depois, a presença de Marine Le Pen no segundo turno das eleições presidenciais pareceu algo normal. Atualmente é ela quem lidera a oposição a Emmanuel Macron. Quando Nicolas Sarkozy era Ministro do Interior, ele prometeu "limpar" os banlieues (subúrbios de maioria populacional formada pela classe trabalhadora e minorias étnicas), e como presidente ele criou um 
Ministério de Imigração e Identidade Nacional. Em um clima de tensão agravado por ataques terroristas, o governo federal sob o mandato do Presidente Socialista François Hollande adotou ainda mais a agenda da extrema direita. O chefe de governo, Manuel Valls, proclamou primeiro um Estado de Emergência e então fez uma tentativa (mal sucedida) de aprovar leis caçando a cidadania francesa dos terroristas, em um contexto de violência indiscriminada. A retórica da república abriu caminho para medidas de "segurança". Dissidentes políticos e movimentos sociais contrários ao governo foram apresentados como uma ameaça à segurança nacional ao mesmo tempo em que o Estado adotava uma política de discriminação e suspeita contra as populações de origem pós-colonial. Estas últimas, vistas como uma fonte de terrorismo são as que mais têm dupla cidadania e, portanto, são as mais ameaçadas de terem sua nacionalidade francesa caçada. Se realmente precisamos de um Estado autoritário e xenófobo para garantir a segurança nacional, a Frente Nacional será sempre a força política mais apta para isto. As leis especiais que Macron decidiu manter incluem muitas propostas que a Força Nacional defende.

Governos, tanto de direita quanto de esquerda, têm implementado políticas de austeridade, como tem feito o governo francês, que se apresenta sendo tanto de direita quanto de esquerda. Em resposta a isto, Marine Le Pen afirma que defende os interesses das classes populares os "franceses do estoque francês". É o bastante para atrair um setor do eleitorado popular que de início se refugiou na abstenção em resposta ao seu abandono da esquerda e sua perda de compasso político.

\section{Populismo}

Muitos estudiosos retratam os movimentos e os partidos de extrema-direita como uma nova família política com base em uma ideologia partilhada, "o nacional-populismo" (Camus e Lebourg, 2015). Na França, este conceito surgiu nos meados dos anos 1980, graças à PierreAndré Taguieff que tentou dar uma definição mais sistemática ao termo ${ }^{8}$. À primeira vista, este conceito parece mais pertinente hoje do que trinta anos atrás, já que agora há uma diferença mais óbvia entre um partido como a Frente Nacional e o fascismo clássico. Mas o conceito de populismo foi tão amplamente usado que suscita um robusto e justificado ceticismo. Por um lado, sua livre flutuação e seus limites abrangentes o tornam quase

\footnotetext{
${ }^{8}$ Confira a contribuição de Rioux (2007).
}

Revista de Estudos e Pesquisas sobre as Américas V.13 N.2 2019 ISSN: 1984-1639 
incompreensível; por outro lado, é impossível falar de populismo como um fenômeno político totalmente desenvolvido, com um perfil e uma ideologia próprios. Há certo consenso entre os historiadores de que este termo se aplica a alguns fenômenos do século dezenove, a exemplo do populismo russo e do populismo americano (os Narodniks desde 1860, o agrário Partido do Povo entre 1892 e 1896), o Boulangismo na França nos primeiros anos da Terceira República, ou a grande variedade de populismos latino-americanos no século $\mathrm{XX}^{9}$, mas o populismo é acima de tudo um estilo de política e não uma ideologia. Trata-se de uma retórica que consiste em exaltar as virtudes "naturais" do povo em oposição às da elite - e da própria sociedade em relação ao establishment político - com objetivo de mobilizar as massas contra "o sistema". Podemos ver esta retórica em uma grande variedade de líderes políticos e movimentos. Nos últimos anos, as acusações de "populismo" foram dirigidas contra Nicolas Sarkozy, Marine Le Pen, Jean-Luc Mélechon na França: Nigel Farage e Jeremy Corbyn no Reino Unido; Silvio Berlusconi, Matteo Salvini e Beppe Grillo na Itália; Viktor Orbán na Hungria e Pablo Iglesias na Espanha; Donal Trump e Bernie Sanders nos EUA; e Hugo Chávez na Venezuela, Evo Morales na Bolívia, Rafael Correa no Equador; Nestor Kirschner e sua esposa Cristina na Argentina. Perante essas enormes diferenças entre essas figuras, a palavra "populismo" tornou-se uma concha vazia que pode ser preenchida por conteúdos políticos dos mais disparatados. Tendo em vista a elasticidade e a ambiguidade do conceito de populismo, Marco d'Éram assinala que ele tem mais a ver com aqueles que o usam do que a quem ele se aplica: é uma ferramenta política útil para estigmatizar adversários. Ao estigmatizar seus adversários políticos de "populistas" se está, antes de tudo, mostrando o desdém que se tem pelo povo. Quando a ordem neoliberal estabelece como norma política a austeridade e as desigualdades sociais, todos que contra ela se posicionam, são automaticamente chamados de populistas (D’Eramo, 2013). "Populismo" é uma categoria usada como mecanismo de autodefesa das elites políticas que sempre estão distante do povo. Diz Jacques Ranciére:

\footnotetext{
Populismo é o nome conveniente para dissimular a contradição exagerada entre legitimidade do povo e legitimidade do especialista, ou seja, a dificuldade do governo em se adaptar às manifestações da democracia e mesmo para a forma mista do sistema representativo. Este nome, de imediato, mascara e revela o desejo intenso do oligarca: governar sem povo, em outras palavras, sem dividir o governo com o povo; governar sem política (Ranciére, 2006, p.80).
}

\footnotetext{
${ }^{9}$ São trabalhos clássicos nessa temática Venturini, 1996; Kazin, 1998; Sternhell, 1997; Zanatta, 2013.
}

Revista de Estudos e Pesquisas sobre as Américas V.13 N.2 2019 ISSN: 1984-1639 
Ao julgar pelos jornais europeus, El País, La Repubblica, Le Monde, The Guardian e Frankfurter Allgemeine Zeitung, o crescimento do populismo está enraizado tanto de políticas sociais - o confronto com a austeridade, a luta pelo aumento do salário mínimo, a defesa dos serviços públicos, e a rejeição aos cortes nos gastos públicos - quanto do apoio à xenofobia e ao racismo. Este é apenas um exemplo da confusão que a palavra populismo pode produzir. De acordo com esta lógica, qualquer um que critica a política neoliberal da troika, é um populista. O Syriza da Grécia (até 2015) e o Podemos da Espanha foram definidos como populistas. Qualquer político anti-establishment pode ser colocado no mesmo saco, quando se ignora as diferenças ideológicas entre eles. O conceito de populismo elimina a diferença entre esquerda e direita e afasta a possibilidade de se entender a política.

Mesmo as tentativas mais nuançadas, informadas e rigorosas de conceituar populismo, caem inevitavelmente, nesta armadilha epistemológica. O populismo se transforma numa categoria abstrata formalizada por um conjunto de características gerais - autoritarismo, nacionalismo radical entendido como religião política, liderança carismática, rejeição ao pluralismo e ao controle da lei, uma visão monolítica e homogênea do povo, uma retórica demagógica entre outras - categoria esta na qual alguns movimentos de esquerda e de extrema direita se enquadram. No entanto, para se definir esta categoria abstrata, pode-se ignorar tanto as genealogias históricas quanto seus objetivos sociais e políticos, que divergem dramaticamente entre si. Se, conforme com a avaliação de Federico Finchelstein, "o populismo é uma forma autoritária de democracia que surgiu originalmente como uma reformulação do fascismo de pós-guerra", uma matriz à qual permaneceria ligado "genética e historicamente", é muito difícil entender sua tipologia que inclui "o populismo neoclássico da esquerda", corrente política a qual pertencem Hugo Chavez, Rafael Correa e Evo Morales na América Latina e também o Podemos e Syriza na Europa (Finchelstein, 2017, p.98, 251, 101). Isaiah Berlin não estava completamente errado quando em sua velha sabedoria conservadora, ele mencionou a futilidade de um tipo de "populismo platônico". Ele dizia que muitos acadêmicos adquiriram um curioso complexo de Cinderela: "há um sapato - a palavra populismo - para o qual em algum lugar, deve existir um pé"10.

Outro exemplo pode também jogar uma luz sobre esta falta de compreensão. Embora sejam muitas vezes eles sejam reunidos sob o mesmo rótulo de "populismo" há uma diferença

\footnotetext{
${ }^{10}$ Palavras de Isaiah Berlin numa conferência sobre o populismo ocorrida em 1967 na London School of Economics, citado por Finchelstein, 2017, p.128.
}

Revista de Estudos e Pesquisas sobre as Américas V.13 N.2 2019 ISSN: 1984-1639 
fundamental entre o populismo latino-americano e o pós-fascismo. Quando olhamos o estilo político de Hugo Chaves vemos que ele foi um populista por excelência. Usou com frequência a demagogia como técnica de comunicação e regularmente convocava o povo quando lhe parecia necessário. Por vezes, ele estava certo em convoca-lo: em 2002 foi uma revolta popular que o salvou de um golpe de estado organizado pela direita venezuelana e pela embaixada dos Estados Unidos. Independente de seus limites, o populismo latino-americano buscou redistribuir riqueza e incluir no sistema político aqueles setores da sociedade geralmente excluídos (de la Torre, 2016, 61-76). A economia política destas experiências é certamente assunto para uma discussão posterior - a incapacidade de usar a renda do petróleo, que é quase a totalidade da riqueza do Estado, para diversificar a economia venezuelana, levou o país à uma catástrofe após a queda do preço do barril de petróleo - mas os objetivos dos populismos latino-americanos são principalmente sociais. A liderança carismática e a deliberação plebiscitária não são certamente formas de democracia, mas as campanhas contra esses governos pelo El País e pelo Financial Times estão enraizados em várias motivações: na América Latina, o populismo era a forma mais consistente de resistência política contra a globalização neoliberal.

Diferentemente, os partidos populistas da Europa Ocidental são caracterizados pela xenofobia e pelo racismo e têm por objetivo principal excluir as camadas mais baixas, mais precárias e marginais da população, o que significa todos os imigrantes. Marco Revelli está certo ao definir o populismo da direita como uma "desordem senil" da democracia liberal, uma "revolta do incluído" que foi empurrado para as margens (Revelli, 2017, p.4). Considerando esta diferença radical, os conceitos de "populismo" e "nacional-populismo" ao invés de ajudar a elucidar os termos só criam confusão. Eles focam-se apenas sobre o estilo político, ou seja, os conceitos podem servir tanto para a direita quanto para a esquerda, obscurecendo assim sua natureza fundamental. Deste ponto de vista, o populismo é irmão gêmeo do "totalitarismo" que é um outro conceito de sucesso que serve apenas para enfatizar algumas semelhanças superficiais entre fascismo e comunismo ao retratá-los como regimes políticos partilhando uma natureza comum. Tanto o populismo como o totalitarismo são categorias que pressupõem uma visão do liberalismo clássico como uma norma histórica, filosófica e política. Eles também pressupõem um olhar externo e aristocrático, vindo de observadores distantes que adotam uma atitude superior e condescendente em relação a um 
vulgus $^{11}$ imaturo e perigoso. Mesmo um analista cuidadoso como Jan-Werner Müller, cujo ensaio sobre o populismo é um exercício de crítico aos frequentes abusos que se faz deste conceito, termina considerando-o como uma advertência para nossos governantes, surpreendidos pela profunda crise das formas de institucionais de representação das democracias liberais (Müller, 2016, p.103). Marco D’Eramo escreveu uma resenha sobre o ensaio de Muller:

O discurso convencional sobre o populismo hoje é produto de intelectuais que se consideram conselheiros do Príncipe. Naturalmente, os autores deste discurso não se vêm como parte do "povo", a quem tratam de forma paternal, examinando-os às vezes benevolência e mais frequentemente com exasperação e impaciência, para dizer não com alarme (D’Eramo, 2017, p.135).

\section{Trump}

A vitória de Donald Trump nas eleições norte-americanas de 2016 levou o eixo político mundial à direita, cujas consequências são sentidas em nível global, mesmo na Europa. É preciso, no entanto, analisar essa vitória cuidadosamente em seu próprio contexto. O resultado final foi tão mais surpreendente e traumático porque, até à véspera das eleições, sentia-se uma vitória certeira de Hillary Clinton. De acordo com o New York Times, a candidata democrata tinha mais de 80 por cento de chances de vencer, e após sua derrota, seus leitores tiveram a impressão de terem sido arremessados para dentro de um pesadelo, de terem experimentado uma história contra-factual na vida real. As pessoas sentiram como se estivessem vivendo em uma realidade alternativa, como foi a vitória de Charles Lindbergh nas eleições fictícias de 1941 descritas por Philip Roth em seu livro Complô contra a América, ou nos Estados Unidos pós-Guerra dominados pelo Japão imperial e a Alemanha nazista no livro O homem do castelo alto de Philip K. Dick, ou na vitória de Robert E. Lee contra a União retratada na série Confederate da rede $\mathrm{HBO}$.

Por terem considerado que a vitória de Clinton seria inevitável, o sucesso de Trump foi sentido como uma violação de uma "lei da história". Para um italiano, entretanto, isso foi muito menos surpreendente, após nossos vinte anos de berlusconismo ${ }^{12}$. Já estávamos bem apáticos, apesar do óbvio reconhecimento de que a vitória de Trump trará efeitos muito mais

\footnotetext{
${ }^{11}$ Termo de origem latina que pode significar povo, massa, multidão, turba.

${ }^{12}$ Referência ao período de governo do Primeiro-Ministro italiano, Silvio Berlusconi.
}

Revista de Estudos e Pesquisas sobre as Américas V.13 N.2 2019 ISSN: 1984-1639 
fundamentais. Se olharmos mais de perto nos resultados das eleições nos Estados Unidos, chegaremos a uma conclusão clara: o que a mídia deixou de prever não foi uma gigantesca onda do neoconservadorismo, o que de fato não ocorreu, mas sim o colapso do voto democrata. Trump ganhou devido às peculiaridades do sistema eleitoral norte-americano, em que conseguira muito menos votos não apenas que Hillary Clinton (recebeu quase três milhões de votos a menos que ela), assim como de Mitt Romney em sua campanha em 2012. Sua vitória deveu-se ao colapso de Clinton em uma série de redutos que tradicionalmente em democratas. O que se vê não é a "fascistização" dos Estados Unidos, como se o país tivesse sido hipnotizado por um novo líder carismático; mas sim a profunda rejeição do establishment político e econômico, com abstenção em massa e o voto de protesto capturado por um político demagogo e populista.

Durante toda a campanha foram traçados paralelos entre Trump e Benito Mussolini. Trump foi definido como fascista não apenas pelas publicações da esquerda liberal, como The Nation e The New Republic, mas também colunistas do The New York Times e o Washington Post (incluindo o analista neoconservador Robert Kagan), e até mesmo a ex-Secretária de Estado Madeleine Albright (Kagan, 2016; Albright, 2018). Essas análises eram, frequentemente, superficiais, tinham como foco a personalidade do candidato republicano. Elas sublinhavam aqueles traços que mais remetiam com os de líderes fascistas clássicos: Trump se apresenta como um "homem de ação" e não de pensamento; ele dá vazão ao seu sexismo ofensivo, ostentando sua virilidade de modo particularmente vulgar e ultrajante; ele arma a xenofobia e o racismo como instrumentos de propaganda, prometendo expulsar muçulmanos e latinos do país, prestando homenagens à polícia quando esta mata negros norte-americanos, e até sugerindo que, devido à sua ascendência familiar, Obama não seria de fato um norte-americano. Sua promessa de ‘tornar a América [sic] grande outra vez’ significa, no final das contas, torná-la branca novamente (Shatz, 2017, p.17). Ele jogou com o chauvinismo de seu eleitorado e se apresentou como defensor das classes populares mais atingidas pela desindustrialização e pela crise econômica que exacerbou as desigualdades sociais desde 2008 (Douthat,2017). Cada vez que aparece na televisão, seu carisma sobressai e adentra os lares de famílias norte-americanas: ele não esconde seu autoritarismo e se utiliza de demagogia para contrastar a situação de norte-americanos comuns (dos quais ele não faz parte e sempre explorou) e o sistema político corrupto de Washington. Nos debates televisionados com Hillary Clinton, ele sempre tratou de a ameaçá-la mandar à prisão uma 
vez que fosse eleito presidente. Embora estes traços fascistas sejam inegáveis, o fascismo em si não se reduz à personalidade de uma liderança política específica.

Não foi um movimento de massa fascista que elevou Trump ao poder, mas seu estrelato televisivo. Nessa perspectiva, seria mais apropriado compará-lo com Berlusconi do que com Mussolini. Trump não ameaça trazer um exército de camisas negras (ou camisas pardas) em marcha a Washington, pelo simples fato de que não há um grupo organizado por trás dele. Ele foi capaz de incorporar a indignação popular contra as elites de Wall Street e Washington, das quais a família Clinton havia se tornado símbolo. Isso apesar de ele ser representante da elite econômica do país. A luta pessoal de Trump contra o establishment é ainda mais paradoxal devido ao fato de ele ser o candidato do Partido Republicano, o chamado Grand Old Party (GOP) que é tido como um dos pilares desse mesmo establishment. Até o momento, ele tem se mostrado mais eficaz em transformar o GOP - a maioria dos mais importantes nomes do Partido Republicano se distanciou de sua candidatura durante a campanha eleitoral - que em construir um movimento fascista. Trump tem conseguido explorar a crise de identidade do Partido Republicano e a perda de marcos ideológicos, crise que vem o caracterizando desde o fim da era Bush. Enquanto representa uma virada autoritária no terreno político, no socioeconômico ele tem demonstra certo ecletismo. Ele é tanto protecionista quanto neoliberal: por um lado, busca pôr fim ao tratado de livre comércio com o México e estabelecer barreiras alfandegárias com a Europa e a China; de outro, busca uma diminuição radical de impostos e a privatização completa de serviços sociais. Está, assim, decidido pelo desmantelamento da modesta política social do governo Obama, particularmente no que diz respeito à área da saúde.

Desde este ponto de vista, a nova direita europeia, com sua oposição ao euro é bem mais 'social' que Trump. Nos Estados Unidos, foi Bernie Sanders quem representou a oposição social ao establishment. O fascismo clássico não era neoliberal; era estatista e imperialista, promovendo políticas de expansão militar. Trump é anti-estatista e bastante isolacionista; agradaria-lhe pôr fim às guerras do país e (apesar de múltiplas contradições) buscar uma reconciliação com a Rússia de Putin. O fascismo sempre apoiou a ideia de uma comunidade nacional ou racial, enquanto Trump prega individualismo. Ele incorpora a vertente xenófoba e reacionária do norte-americanismo: o self-made man de um darwinismo social, o justiceiro que defende seu direito ao porte de armas, o ressentimento dos brancos que estão se tornando minoria em um país de imigrantes. Ele garantiu o voto de um quarto do 
eleitorado ao acertar na interpretação do medo e das frustrações de uma minoria, assim como fez o nacionalismo $W A S P^{13}$ há um século quando se levantou contra a chegada de imigrantes católicos, ortodoxos e judeus da Europa meridional e oriental.

Poderíamos definir Trump como um líder pós-fascista sem o fascismo, compreendendo - seguindo o historiador Robert O. Paxton - que o comportamento fascista do presidente norte-americano é inconsciente e involuntário, pois é bem provável que nunca tenha lido um único livro sobre Hitler ou Mussolini ${ }^{14}$. Trump é descontrolado e imprevisível. Quando colocamos tudo em perspectiva histórica adequada, fica claro reconhecer que isso que observamos se difere do fascismo clássico. Podemos traçar analogias por meio de comparações históricas, mas não mapear o perfil de Trump dentro de um paradigma fascista do período entre guerras. O contexto é, simplesmente, diferente demais.

Pode-se dizer que Trump está tão distante do fascismo clássico como o Ocupe Wall Street, o movimento espanhol 15-M, e o movimento francês Nuit Debout ${ }^{15}$ estão do comunismo do século XX. A oposição social e política entre essas forças é tão profunda quanto a oposição histórica entre o comunismo e o fascismo. Não se deve concluir, a despeito da analogia, que os sujeitos em questão se entendem como herdeiros dessa história do Século XX. Neste sentido, ao falar do "fascismo" de Trump não é estabelecer uma continuidade histórica ou que há um legado adotado de maneira consciente pelo mesmo. Sem dúvida, há fortes semelhanças. De acordo com suas afirmações, Trump estaria defendendo as classes populares que sofreram com a desindustrialização e a crise econômica de 2008, embora, em vez de manifestar-se contra o principal responsável - o capital financeiro -, aponta bodes expiatórios. Em sua campanha eleitoral também foram reproduzidos elementos do antisemitismo fascista dos anos 1930, que defendia uma comunidade nacional etnicamente homogênea e mítica. Enquanto os judeus foram o inimigo específico do fascismo, Trump alterou e aumentou a lista para incluir os negros, os latinos, os muçulmanos, e os imigrantes não-brancos. A eleição revelou a enorme divisão entre os segmentos rural e urbano dos Estados Unidos (Trump perdeu em todas as cidades, incluso nos estados em que ganhou

\footnotetext{
${ }^{13}$ A sigla WASP (White Anglo-Saxon Protestant) é um acrônimo comum nos Estados Unidos que se refere a um grupo social específico dentre os brancos, os protestantes anglo-saxônicos, marcando distinção social em relação a outros brancos (N.T.).

${ }^{14}$ Veja a entrevista de Isaac Chotiner com Paxton, 'Is Donald Trump a Fascist?' in Slate, 10 February 2016.

15 Trata-se de um movimento social francês anti-austeridade que teve início ao final de março de 2016 , decorrente de protestos contra as reformas trabalhistas propostas conhecidas como a lei El Khomri ou Loi travail (N.T.).
}

Revista de Estudos e Pesquisas sobre as Américas V.13 N.2 2019 ISSN: 1984-1639 
acima de 60 por cento dos votos), demonstrando a ligação duradoura entre crises econômicas e xenofobia. Frente ao crescimento irrefreável do multirracialismo, medo e a reação xenófoba se alastraram nas comunidades brancas norte-americanas. A política baseada em bodes expiatórios se utiliza disso e o amplifica. Na retórica de Trump, a palavra "establishment" reproduz e reformula o velho chavão antissemita da comunidade serena, harmoniosa e virtuosa enraizada na terra que se encontra ameaçada pela metrópole corrupta, cosmopolita, intelectual e anônima.

Algumas analogias feitas são caricatas, beirando paródias. Vídeos de Trump em que, após a aterrissagem de seu avião particular, ele desce à pista e se dirige a um aglomerado um grupo empolgado de indivíduos armados com seus telefones celulares, que os seguram para tirar fotos em uma estranha substituição à saudação fascista - lembram as cenas que abrem o filme de Leni Riefenstahl, $O$ triunfo da vontade, sobre o comício nazista em Nuremberg de 1936, em que Hitler sobrevoa a cidade antes de ser recebido por uma multidão delirante. Essa analogia é, no entanto, apenas acidental. Ao contrário de Mussolini ou Hitler, é bem provável que Trump nunca tenha lido A multidão: um estudo da mente popular (1895) de Gustave Le Bon (2002) - a "bíblia" de lideranças carismáticas da velha guarda - e sua habilidade enquanto demagogo se explica pela familiaridade com os códigos da televisão. É provável que muitos de seus apoiadores estivessem sob F (fascista), na classificação de 1950 que Erich Fromm e Theodor Adorno traçaram da "personalidade autoritária" (Adorno, 1950). O fascismo não é reduzível, no entanto, ao temperamento de um líder e nem (apesar de sua importância) à disposição psicológica de seus seguidores.

O problema se encontra precisamente no fato de que ele não traz um programa, o que o distingue do fascismo histórico. O fascismo foi capaz, dentro do contexto catastrófico do período entre guerras e a despeito de seu ecletismo ideológico, de propor uma alternativa totalizante àquilo que aparentava ser uma ordem liberal decadente. Isto é, o fascismo apresentou um projeto de sociedade, de uma nova civilização. Trump não promove nenhum modelo alternativo para a sociedade. Seu programa limita-se ao slogan "tornar a América [sic] grande outra vez”. Ele não busca mudar o modelo socioeconômico dos Estados Unidos, pelo simples fato de que se beneficia enormemente do mesmo.

O fascismo emergiu de uma época de forte intervencionismo estatal na economia, característica compartilhada pela União Soviética, pelos países fascistas e pelas democracias ocidentais, começando com o "New Deal" de Roosevelt. Nasceu na era do capitalismo 
fordista, da linha de produção e da cultura de massa. Já Trump emergiu na era do neoliberalismo, do capitalismo financeiro, do individualismo competitivo e da precariedade endêmica. Em vez de mobilizar as massas, atrai uma massa de indivíduos atomizados, de consumidores empobrecidos e isolados. Ele não criou um novo estilo político, nem busca se assemelhar a um soldado ou utilizar um uniforme. O estilo de vida que ostenta, de uma exuberância chinfrim, imita o set de seriados hollywoodianos. Trump incorpora o modelo antropológico neoliberal. Difícil é imaginar Mussolini ou Hitler agindo como promotores imobiliários. Isto é o que separa Trump dos movimentos nacionalistas, racistas e xenófobos da velha Europa, pois esta busca um grau de respeitabilidade ao se desligar de suas origens fascistas. Embora os Estados Unidos nunca tenham tido um presidente tão à direita, as ideais fascistas são, paradoxalmente, menos ubíquas em relação a sessenta ou cem anos atrás, durante o macarthismo ou a caça às bruxas da ameaça vermelha.

Isso não quer dizer que a vitória de Trump seja um evento isolado. Ela faz parte de um contexto internacional que inclui também a crise da União Europeia, ao Brexit e às eleições presidenciais da França de 2017. Faz parte de uma tendência geral de emergência de movimentos que buscam desafiar os poderes estabelecidos e até mesmo a globalização (o euro, a União Europeia, o establishment norte-americano), até certo grau, a partir da direita. Essas forças em ascensão mapeiam uma espécie de constelação pós-fascista. Esta é, entretanto, uma tendência heteróclita que junta diversas correntes de genealogias bastante variadas.

\section{"Antipolítica"}

Se o "populismo" é frequentemente definido como uma forma de "antipolítica", é preciso sublinhar a importância que este termo realmente exprime. De acordo com Pierre Rosanvallon (2008, p.22), o populismo seria uma forma "patológica" da política, isto é, a "política pura do não político" (la politique pure de l'impolitique). O triunfo do "não político" (ou a antipolítica) significa, simplesmente, que a democracia representativa está paralisada e, em última análise, "vampirizada" pela "contra-democracia", um conjunto de contrapoderes necessários à democracia precisa mas que são suscetíveis de mata-la. Embora possa parecer um retorno ingênuo a Rousseau, instrumentos utilizados para avaliar e colocar controles sobre o poder - referendos, transparência, controles permanentes, eliminação de corpos intermediários entre cidadãos e o poder - podem destruir uma democracia quando põem o 
próprio princípio em causa da representação $\mathrm{Na}$ leitura de Rosavallon, estes contrapoderes criam uma lacuna "entre a sociedade cívica-civil e a esfera política", podendo estar ter resultados úteis ou perigosos: por um lado, "uma vigilância cívica saudável pode encorajar uma desconfiança social e pressionar o governo a atender às demandas sociais"; por outro, "também pode incentivar formas destrutivas de difamação e negatividade" (Idibem, p.253, p.24).

$\mathrm{Na}$ definição do filósofo Roberto Esposito, "o impolítico" seria uma abordagem desiludida em que a política é reduzida à pura "factualidade", à pura materialidade: Tornou-se obsoleta a visão clássica schmittiana da política moderna enquanto uma forma secularizada da velha teologia política (Esposito, 2015; Schmitt, 2006). A política moderna consiste a sacralização de instituições seculares - começando pelo poder soberano do Estado, logo o Parlamento e a Constituição - para tomar o lugar da velha monarquia baseada no direito divino. Substituíram-se emblemas e liturgias do absolutismo por rituais e símbolos republicanos. Nesta visão, valores são incorporados pelas forças políticas; a representação política carrega uma conotação quase sagrada e o pluralismo é expressivo de um conflito de ideias, carregado por um compromisso intelectual poderoso. Os estadistas de hoje em dia se consideram universalmente bons gestores pragmáticos (e o mais importante, "pósideológicos”). Não incorporada por valores, a política tornou-se um espaço para a “governança” pura e a distribuição de poder, de administração de grandes recursos. O campo político deixou de ser um espaço para a combate de ideias, para se tornar um em que se dá a construção de carreiras. O "impolítico" revela a realidade material que está na base da representação política. O que hoje se acostuma chamar de "antipolítica" é a reação contra a política contemporânea, que foi despojada de seus poderes soberanos - sobrevivendo enquanto instituições vazias - e reduzida à sua "constituição material" - o "impolítico" - isto é, uma amálgama de poderes econômicos, máquinas burocráticas e um exército de intermediários políticos.

O populismo, tido como a personificação da "antipolítica", tem inúmeros críticos. A maioria, no entanto, se silencia em relação às suas reais causas de suas críticas. A antipolítica é resultado do esvaziamento da política. As últimas três décadas, a alternância de poder entre a centro-esquerda e a centro-direita não significou nenhuma mudança essencial nas políticas governamentais. Isso porque a alternância de poder significa uma mudança do pessoal que administra os recursos públicos, em que cada um se utiliza das próprias redes e estruturas 
patronais, em vez de uma mudança em políticas governamentais. Esta novidade se combina com duas outras transformações significativas na sociedade civil e a política estatal. Por um lado, vemos uma crescente reificação do espaço público - o local de um uso crítico da razão em que as ações das autoridades são analisadas e criticadas (Habermas, 1991) - pois este espaço foi absorvido pelos monopólios midiáticos e pela indústria da comunicação. Por outro lado, a tradicional separação de poderes é questionada por uma contínua mudança de prerrogativas do poder legislativo para o executivo. Nesse permanente Estado de exceção a função original de criação de leis dos parlamentos se desloca para a de ratificação de leis já desenhadas pelo executivo. Em tal contexto, o crescimento do 'anti-político' é inevitável. Aqueles críticos que denunciam a 'antipolítica' populista muitas vezes são os mesmos responsáveis por essas transformações: piromaníacos disfarçados de bombeiros.

O pós-fascismo não carrega os valores "fortes" de seus ancestrais da década de 1930, porém pretende preencher o vácuo aberto pela política reduzida ao impolítico. Com receitas politicamente reacionárias e socialmente regressivas, abrangem a restauração da soberania nacional, a adoção de formas de protecionismo econômico, assim como a defesa de “identidades nacionais" ameaçadas. À medida que a política caiu em descredito, os pósfascistas defenderam um modelo plebiscitário da democracia que destrói qualquer processo de deliberação coletiva, favorecendo aquela relação que funde o povo e o líder, a nação e seu chefe. O termo "impolítico" tem uma longa história que remonta a com Thomas Mann, um dos principais representantes da Revolução Conservadora alemã do final da Primeira Guerra Mundial (Mann, 1983). Mas as formas contemporâneas da antipolítica não são, entretanto, exclusividade da direita. O Movimento Cinco Estrelas na Itália encarna uma crítica regressiva da democracia representativa, e ainda consegue canalizar a busca por uma alternativa à atual crise da política. No entanto, está claro que quaisquer tentativa de estigmatizar a "antipolítica" por meio da defesa da política realmente existente já está fadada a falhar.

As novas forças da direita radical têm algumas características em comum - em primeiro lugar, a xenofobia, com uma retórica renovada. Eles abandonaram os velhos chavões do racismo clássico, ainda que sua xenofobia seja de fato direcionada contra imigrantes ou povos de origem pós-coloniais. Em segundo lugar, a islamofobia, núcleo desse novo nacionalismo, tomou o lugar no antissemitismo. Retornaremos a esse ponto. Decerto, terão outros temas em comum, mas o nacionalismo, a antiglobalização, o protecionismo e o autoritarismo podem apresentar-se de modos bastante diferentes, com algumas mudanças 
ideológicas entre si. A Frente Nacional deixou de pleitear a reintrodução da pena de morte, mas reivindica um governo forte e um Estado soberano que se recusa a submeter-se ao poder das finanças: propõe um nacionalismo autoritário e autárquico.

Mesmo sem um embasamento ideológico forte, tal discurso apresenta um grau de coerência. A retórica militarista e imperialista de Mussolini, Hitler e Franco perdeu sua credibilidade. O pós-fascismo, por sua vez, não se interessa por reconstruir os impérios coloniais nem impulsionar a guerra. Sua oposição às guerras ocidentais no Oriente Médio aparenta um "pacifismo". Até mesmo o fascismo clássico se caracterizava pela incoerência, a tensão, e o conflito. Variadas tendências se agrupavam sob o fascismo italiano e o nazismo alemão, da vanguarda futurista ao romanticismo conservador, de mitologias agrárias à eugenia. Mais adiante veremos como o fascismo francês era uma galáxia de forças políticas, "ligas" e grupos muito além da "Revolução Nacional" de marechal Pétain. A ideologia desempenhou, nas décadas de 1920 e 1930, um papel de grande importância nessa galáxia - e seguramente muito além daquilo que vemos nas forças contemporâneas da direita radical. Por de trás da Frente Nacional não vemos figuras intelectuais comparáveis às lideranças da Action Française, Maurice Barrès e Charles Maurras, ou com os expoentes do colaboracionismo na Paris e Bruxelas sob ocupação nazista.

\section{Intelectuais}

Algumas tentativas de renovar a extrema direita e de transformar suas formas políticas ocorreram na França nas últimas décadas, mas mesmo sua corrente mais dinâmica e sofisticada, o $G R E C E^{16}$, que se enquadra mais como um círculo intelectual do que como um grupo político. Alain De Benoist, sua mais importante liderança, parece não ter desempenhado papel algum na metamorfose da Frente Nacional. Hoje, a defesa de suas ideias no debate público é assegurada por intelectuais e analistas políticos da televisão como Éric Zemmour e Alain Finkielkraut, que não são nem ideólogos fascistas nem membros do partido. São poucos que, como Renaud Camus, teórico da "grande substituição" da população francesa por imigrantes, que declararam abertamente seu apoio à Frente Nacional. Eles podem ser brilhantes ensaístas e não escondem suas ambições em se tornarem os próximos Maurice

\footnotetext{
16 'Groupement de recherche et d'études pour la civilisation européenne, um think tank reacionário francês fundado por Alain De Benoist em 1968.
}

Revista de Estudos e Pesquisas sobre as Américas V.13 N.2 2019 ISSN: 1984-1639 
Barrès e Charles Maurras, mas a sua influência depende quase que exclusivamente de sua presença esmagadora em programas de entrevista na televisão.

Em seus esforços para alcançar uma respeitabilidade republicana, a Frente Nacional parece estar se distanciando cada vez mais de pensadores neofascistas extremos como Alain Soral. Vale mencionar, ainda, que foi Éric Zemmour (2014) e não Marine Le Pen quem desenrolou uma campanha em torno da ideia da "grande substituição".

Outro sintoma adicional de uma metamorfose inacabada coloca em questão as categorias tradicionais utilizadas para a análise da extrema direita. Além das diferenças entre os casos francês, italiano e alemão, o fascismo clássico ambicionava um novo projeto e uma nova visão de mundo que dariam fundamento para sua política. Definia-se como revolucionário; buscava a construção de uma nova civilização por meio de uma "terceira via" entre o liberalismo e o comunismo (Mosse, 2000). Hoje, a extrema direita não mais se preocupa com isso. Historicamente, houve a necessidade de o nacionalismo fascista se colocar em oposição a algum tipo de "outro". Os primeiros foram os judeus, a visão mítica de uma espécie de antirraça, um corpo estranho cuja intenção era corromper a nação. Somasse a isso uma visão de mundo sexista e misógina em que a mulher seria sempre submissa. Consideradas reprodutoras da raça, as mulheres seriam cuidadoras de lares, criadoras das crianças e não desempenhariam papel algum na vida pública (Koonz, 1987; de Grazia, 1993). Havia, no entanto, exceções: a fascista italiana e ministra da cultura Margherita Sarfatti (que também era judia), assim como a cineasta propagandista nazista Leni Riefenstahl. Outra figura da antirraça, a homossexualidade, era tida como a encarnação da fraqueza moral e da decadência da moralidade que contrariava o culto fascista à virilidade (Mosse, 1998). Nos dias de hoje, essa retórica toda desapareceu, mesmo que a homofobia e o antifeminismo continuem amplamente difundidos entre o eleitorado da direita radical. Muitos desses movimentos alegam, de fato, serem defensores dos direitos das mulheres e pessoas gays contra o islamismo. Pim Fortuyn e, posteriormente, seu sucessor Geert Wilders na Holanda representam exemplos bem conhecidos desse conservadorismo LGBT $^{17}$, mas não são exceções. O Alternative für Deutschland se opõe ao casamento igualitário, porém a líder do partido no Bundestag, Alice Weidel, é lésbica. Florian Philippot, ex-secretário da Frente

\footnotetext{
${ }^{17}$ A sigla refere-se ao movimento da diversidade sexual e de gênero, incluindo lésbicas, gays, bissexuais e transexuais/travestis. Atualmente a sigla completa seria LGBTTIQ+, incluindo além dos mencionados, interssex e queer, de modo que o + inclui as múltiplas identidades de gênero e orientações sexuais que não se enquadram nas demais (N.T.).
}

Revista de Estudos e Pesquisas sobre as Américas V.13 N.2 2019 ISSN: 1984-1639 
Nacional, não esconde sua homossexualidade e Renaud Camus é um ícone do conservadorismo gay francês.

Apesar de personagens da extrema direita se envolverem em movimentos como o Manif pour tous em princípios 2012, que se opôs à introdução do casamento igualitário e da adoção por casais homo-afetivos, Marine Le Pen não marcou posição no assunto. Esse papel foi deixado à sua sobrinha, Marion Maréchal Le Pen, que apesar de influente, não consegue muita visibilidade. Os quadros da Frente Nacional manifestam, na televisão e na rádio, pelo o direito ao uso de minissaias, em objeção aos muçulmanos que supostamente defenderiam a imposição da burca (ou o burquíni ${ }^{18}$ ) e a prática do casamento forçado. Isso tudo faz parte das tensões e contradições do pós-fascismo descritas acima. O pós-fascismo começa com o antifeminismo, o racismo reverso ${ }^{19}$, o antissemitismo, e a homofobia; e cujos impulsos a direita radical continua amontoando. As camadas mais obscurantistas votam na Frente Nacional, apesar da adoção deste de novos temas e práticas sociais que não pertencem ao seu código genético. A posição ambígua de Marine Le Pen em relação ao casamento igualitário e ao Manif pour tour não é, portanto, uma mera decisão tática. É um reflexo da mudança histórica que a extrema direita foi forçada a reconhecer sob o risco de ser marginalizada. As sociedades europeias do século XXI sofreram mudança em relação aos anos 1930: hoje seria um anacronismo defender que o lugar das mulheres deveria se limitar à esfera doméstica, assim como demandar que a Argélia voltasse a ser colônia francesa. Marine Le Pen é produto dessa mudança e tem plena consciência de que manter-se atada aos velhos bordões ideológicos levaria à alienação de amplas camadas da população.

O fato de que a opinião conservadora, da 'maioria silenciosa', estar tomando as ruas foi o que mais impressionou no Manif pour tous (para além do aspecto idiossincrático e ultrarreacionário de certos grupos). Essa ocupação de espaços públicos perpassou a adoção de códigos estéticos oriundos da esquerda - lembremos os cartazes de maio de 1968 - e cujas significações foram invertidas pelos manifestantes. Essa apropriação e redirecionamento de símbolos e slogans que não pertencentes à sua história revelam um grau de 'emancipação' de seus cânones de direita e uma redefinição geral do panorama intelectual (Robcis, 2015).

\footnotetext{
${ }^{18}$ Refere-se a um traje de banho feminino que cobre todo o corpo menos o rosto, as mãos, e os pés (N.T.).

19 No original lemos "anti-Black racism", que traduzido literalmente seria "racismo anti-negro". Assim, preferimos traduzir por "racismo reverso", em acordo com a forma coloquial de seu uso no Brasil (N.T.).
}

Revista de Estudos e Pesquisas sobre as Américas V.13 N.2 2019 ISSN: 1984-1639 
A principal característica do pós-fascismo hoje é, exatamente, a coexistência contraditória da herança do fascismo clássico com os novos elementos que não pertencem à sua tradição. Há, no entanto, desenvolvimentos mais amplos que vêm incentivando essa mudança. A Frente Nacional está se engajando politicamente no mundo contemporâneo, um mundo que atravessa uma profunda metamorfose tanto no campo político como na esfera pública. O século $\mathrm{XX}$ viu grandes partidos de massa, com sua própria fundamentação ideológica, sua própria base social, estrutura nacional e raízes profundas na sociedade civil. Tudo isso mudou. Os partidos políticos não precisam mais apresentar um arsenal ideológico. Em toda a Europa, o recrutamento de intelectuais, por partidos governantes tanto da esquerda como da direita, deu lugar ao recrutamento de profissionais de publicidade e comunicação. $\mathrm{O}$ mesmo vale para a Frente Nacional, que cuida assiduamente de sua imagem, seus slogans, e seus principais argumentos. O estilo político está se tornando cada vez mais importante, à medida que a ideologia desaparece. Diante desse novo contexto, o nacionalismo não mais busca definir a comunidade nacional em termos raciais, culturais ou religiosos, mas a partir de uma resistência contra a ameaça da globalização. Donald Trump representa, nitidamente, um caso extremo desse ecletismo 'antipolítico' e pós-ideológico. Durante sua campanha houve um esforço de não se alinhar com ideologia alguma, e mesmo os elementos mais conservadores do Partido Republicano mantiveram uma distância de Trump. Com a mudança de postura em diversos assuntos de um dia para o outro, Trump nunca abandou sua postura "anti-establishment".

\section{Nação}

As nações foram por muito tempo definidas em termos "objetivos" - comunidades estáveis, enraizadas em territórios definidos naturalmente, povos etnicamente homogêneos, unificados em suas economias, culturas, línguas e religiões. As nações eram quase entidades ontológicas dotadas de um destino providencial, do qual a história era seu reflexo. Nestas últimas décadas, estudiosos começaram a repensar as nações enquanto construções socioculturais, seguindo a obra pioneira de Benedict Anderson (1983) Comunidades Imaginadas. $\mathrm{Na}$ esfera pública, a antiga retórica nacionalista diminuiu e o discurso conservador mudou seu foco da nação para a identidade nacional. Quase toda a direita reformulou "a nação" em termos de identidade. Na Itália, a extrema direita tem sido 
antinacionalista em sua xenofobia, como foi o caso da Lega Nord, que buscava inicialmente separar o norte rico e "europeu" do sul pobre, mediterrâneo. A partir de 2013, seu líder Matteo Salvini buscou mudar isso se aliando aos neofascistas - como o movimento CasaPound - e substituindo a linha antissul original da Lega com uma xenofobia generalizada $^{20}$. Na França, Nicolas Sarkozy foi quem inaugurou a virada "identitária" antes mesmo de ser adotada por Marine Le Pen. Ela pertencente a uma geração que nunca sofreu os traumas que o nacionalismo francês do século XX conheceu: Le Pen não testemunhou nem o regime Vichy, nem a guerra contra a Argélia. Sua formação política se deu num cenário em que todos os elementos constitutivos do fascismo já haviam desaparecido. Havia ainda, nas décadas de 1970 e 1980, muitos que sentiam nostalgia por Vichy, a Argélia francesa, e a Indochina - hoje, entretanto, não mais.

Longe de dizer que o racismo da extrema direita tenha desaparecido, mas que sua matriz fascista original foi consideravelmente desfocada. Neste sentido, a extrema direita não tem a ideologia como problema. Afinal, a sua relação com o fascismo espelha aquela relação da social democracia com o socialismo. Os partidos socialdemocratas hoje em toda a Europa se adaptaram ao neoliberalismo e se destacaram no desmantelamento daquilo que resta dos Estados de bem-estar social que os mesmos criaram logo após a Segunda Guerra Mundial. O Partido Socialista Francês se opôs, historicamente, ao gaullismo e no final da década de 1950, opunha-se ao advento da Quinta República, tida, pelo partido, como uma virada autoritária. Posteriormente, no entanto, adaptou-se às suas instituições e abandonou seus valores originários em nome de um "realismo" econômico, em que os críticos de suas políticas seriam tachados de "populistas". Aqueles movimentos que sustentam um discurso marxista-leninista e adotam estilos do comunismo entre guerras são meras seitas, uma vez que a grande parte da esquerda radical se afastou de tal retórica. Na França, o Nouveau Parti Anticapitaliste, fundado em 2009, buscou, ao princípio, adotar uma nova linguagem que ultrapassasse o velho discurso marxista revolucionário. Se os programas do Podemos, e mesmo do Syriza no momento de sua primeira vitória eleitoral em 2015, se colocam em oposição radical ao neoliberalismo, os mesmos são moderados se comparados aos projetos sociais da década de 1970 do programa comum da Union de la Gauche ${ }^{21}$, do SPD alemão ou do Partito Comunista

\footnotetext{
${ }^{20}$ Há uma bibliografia gigantesca sobre a Lega Nord. A respeito de sua última metamorfose em um movimento de extrema direita sob a liderança de Matteo Salvini, ver Valerio Renzi (2015).

${ }^{21}$ Em português União da Esquerda (N.T.).
}

Revista de Estudos e Pesquisas sobre as Américas V.13 N.2 2019 ISSN: 1984-1639 
Italiano. Entramos, simplesmente, em um novo regime da historicidade: no mundo neoliberal, a defesa do Estado de bem-estar social se tornou subversiva. Deste ponto de vista, a “incoerência" ideológica da extrema direita não é nada extraordinária: reflete, apenas, uma mudança à qual quase todas as forças políticas estão sujeitas.

\section{Macron}

As eleições presidenciais francesas de 2017 foram um pequeno terremoto político que questionou radicalmente a dicotomia tradicional entre esquerda e direita que até então tinha estruturado a Quinta República. Neste sentido, elas se comparam ao que aconteceu na Itália no começo dos anos 1990 quando a Democracia Cristã, o Partido Comunista Italiano e o Partido Socialista desapareceram, ou nas recentes eleições espanholas que viram o Podemos e o Ciudadanos emergirem como competidores aos tradicionais partidos de esquerda e de direita (o Partido Socialista PSOE e o Partido Popular). No entanto, a eleição não foi uma virada para a extrema direita como muitos anunciavam e temiam. Como previsto, Marine Le Pen chegou ao segundo turno, com quase 34\% dos votos (acima de 10 milhões de votos). Mas, embora tenha sido o que se esperava - pareceu que ela conseguiria alcançar não só os quarenta por cento, mas também ultrapassar esse limite - esse resultado foi decepcionante para a Frente Nacional e gerou de imediato uma pequena crise entre suas lideranças.

Como explicar tudo isto? Marine Le Pen estava feliz o suficiente para ser colocada como contrapondo ao outsider Emmanuel Macron: do seu ponto de vista, a situação no segundo turno não poderia ter sido mais favorável. Macron, o jovem candidato que ela enfrentou, é uma pura destilação do establishment: formado na ENA (escola da elite francesa) e ex-diretor do banco de negócios Rothschilds e também um ministro da Economia de um governo bastante impopular. O candidato da direita François Fillon foi tragado por escândalos relativos ao uso de seu patrocínio, enquanto a campanha do Partido Socialista ficou paralisada pelo legado de um presidente desacreditado e o surgimento de um opositor da esquerda, o candidato do France Isoumise ${ }^{22}$, Jean Luc Mélechon, um eco do Podemos. Marine Le Pen achava que no enfrentamento com Macron ela poderia aparecer como a candidata de todos os patriotas, dos defensores da soberania nacional, a autêntica representante da França profunda

\footnotetext{
${ }^{22}$ Isonomia Francesa (N.T.).
}

Revista de Estudos e Pesquisas sobre as Américas V.13 N.2 2019 ISSN: 1984-1639 
contra o candidato globalista das finanças internacionais, o homem de Bruxellas e da Troika, muito mais à vontade na City de Londres e em Wall Street do que nas regiões pobres da França. Em resumo, ela estaria ao lado da nação contra o globalismo.

Mas ela não soube aproveitar a oportunidade. Os analistas políticos e mesmo os seus correligionários avaliavam que sua campanha de segundo turno tinha sido fraca e que seu desempenho contra seu adversário no debate de TV do segundo turno das eleições havia sido um desastre. Muitos falaram dos erros táticos e da fraqueza das mensagens, mas talvez houvesse uma razão mais profunda para seu fracasso, provavelmente relacionada às antinomias do pós-fascismo. Sua campanha se enfraqueceu devido à instabilidade fundamental de sua abordagem, que expressava a transição incompleta entre o fascismo do passado (a matriz de seu movimento) e uma direita nacionalista ainda incapaz de comprovar legitimidade ou respeitabilidade de acordo com os cânones da democracia liberal. Durante o debate de TV com Macron, Marine Le Pen não usou uma linguagem fascista. Seu racismo foi suavizado enquanto que sua xenofobia foi aparente e flexionada por uma retórica que é de fato lugar comum entre todos os políticos de direita. Porém, Suas propostas terminaram por parecer serem confusas e vagas: sua abordagem hesitante à pergunta sobre o euro terminou por revelar uma surpreendente incompetência e suas tiradas autoritárias pareceram longe de convincentes: ninguém podia acreditar que sob sua presidência haveria um combate mais efetivo contra o terrorismo. Em síntese, sua retórica agressiva, sua óbvia demagogia, sua inabilidade de formular um argumento e o caráter vago de suas propostas mostravam que aquela candidata não tinha o preparo exigido para um estadista. Marine Le Pen não é mais uma fascista, mas também não se converteu à democracia: ela permanece no equilíbrio entre os dois polos. Não é mais uma fascista, em um mundo que não aceita a ideologia, a linguagem e as práticas do velho fascismo, mas os fantasmas do fascismo continuam a lhe cercar. Também não é uma democrata porque suas palavras mostram que sua conversão à democracia é instrumental, não é sincera e nem autêntica. Provou ser incapaz de ultrapassar o limite de uma simples denúncia e de se apresentar como arauto de uma força de governo confiável. Nas recentes décadas de austeridade e de violência social e econômica provocadas por governos de todas as cores, a Frente Nacional conseguiu canalizar a revolta das classes populares e se tornar o saída para o mal-estar e o sofrimento crescentes em amplas camadas da sociedade, mas não se tornou um partido de governo. Seu avanço e seus limites foram espelhos para 
outros partidos nacionalistas e xenofóbicos da União Europeia, que experimentaram “derrotas" semelhantes nos últimos anos, dos Países Baixos ao Reino Unido e à Dinamarca.

Mais amplamente, as eleições francesas introduziram um novo elemento no debate sobre o populismo. A própria vitória de Macron marcou o surgimento de um novo tipo de populismo, de alguma forma, já conhecido com a eleição de Matteo Renzzi na Itália; um populismo que não é fascista nem reacionário, nem nacionalista e nem xenofóbico, mas de todo jeito, um populismo. Assim como Renzzi, Macron se apresentou como um político livre das ideologias do século XX: para além da esquerda e da direita, ele montou um governo em que os ministros de ambos os lados que trabalham lado a lado em harmonia. Jovem, culto, brilhante, tático, ousado e educado, Macron realmente aprendeu a lição de Maquiavel de que a "virtude" de um autêntico político consiste em sua habilidade de explorar as circunstâncias em que ele está agindo (sua "fortuna") para conquistar o poder. Realmente, ele se deparou com circunstâncias extremamente favoráveis: a esquerda estava exausta pelo desgaste de ter ocupado o poder, a direita estava mergulhada em corrupção e o sistema eleitoral fez com que ele saísse dos $24 \%$ do primeiro turno para um voto por aclamação no segundo turno, jogando com os medos do crescimento da Frente Nacional. Seguindo a lição de Maquiavel, Macron usou de uma linguagem capaz de atrair os votos tanto da direita e quanto da esquerda. Sua política econômica neoliberal favorecerá a elite dominante, e em contraposição será cobrado por políticas sociais em defesa das mulheres, dos homossexuais e minorias étnicas. Ele inclusive ganhou os votos da juventude magrebina e de origem africana quando definiu o colonialismo "como um crime contra a humanidade" e lembrar que os cientistas e empresários do Vale do Silício e de Wall Street são avaliados por suas habilidades e não por suas origens, religião ou cor da pele.

Macron é o grau zero de ideologia. A mídia deslumbrada divulgou seu pedigree como filósofo - ele tinha sido aluno de Paul Ricoeur ${ }^{23}$ - mas além do realismo maquiavélico acima mencionado, sua filosofia política se limita a um pragmatismo radical sob uma fina capa de humanismo. Durante sua campanha para presidente, ele não clamou por apoio a um projeto ou a um conjunto de valores, mas se apresentou como salvador da pátria, o homem da providência. Sua vontade de reformar a França através de decretos presidenciais (inclusive decretos sobre questões fundamentais como da legislação trabalhista) foi uma clara demonstração da supremacia do executivo sobre o parlamento e revela uma propensão

\footnotetext{
${ }^{23}$ Cf. O texto muito agradável de François Dosse (2017).
}

Revista de Estudos e Pesquisas sobre as Américas V.13 N.2 2019 ISSN: 1984-1639 
autoritária que dá à sua presidência um caráter bonapartista. Ele se apresenta como um líder carismático - um "Jupteriano", de acordo com a mídia que lhe apoia. Ele é apoiado pelas instituições europeias, pelos patrões franceses e pelas finanças internacionais, e se gaba de ter destruído o sistema bipartidário da Quinta República, da mesma forma que Renzi se promoveu como o homem que se "desfaria" as velhas lideranças do Partido Democrático. Em resumo, Macron representa um novo populismo neoliberal, pós-ideológico e "libertário"24. Muitos progressistas foram seduzidos pelo charme deste jovem político, cujas maneiras e cultura parecem fazê-lo ser o oposto de um Sarkozy, sem mencionar Berlusconi ou Donald Trump. Entretanto, mais uma vez, como sempre acontece de quando tratamos do populismo, é uma questão de estilo político. Por trás de seus modos afáveis esconde-se uma nova concepção da política que expressa o novo ethos da era neoliberal. Este ethos é a competição, a vida concebida como um desafio organizado de acordo com um modelo empresarial. Macron não é de direita nem de esquerda: ele incorpora o homo economicus que chegou à arena política. Ele não quer colocar o povo contra as elites, pelo contrário ele oferece ao povo as elites como modelo. Sua linguagem é a linguagem dos bancos e empresas: seu desejo é ser o presidente de um povo produtivo, criativo e dinâmico, capaz de inovar e ganhar dinheiro. Mas, se é verdade que as leis do mercado governam o mundo, é verdade também que a vasta maioria do povo será sempre perdedora, o que continuará a alimentar o nacionalismo e a xenofobia. Podemos apostar que cinco anos de "macronismo" não farão a Frente Nacional desaparecer.

\section{Referências}

ADORNO, Theodor W., "The Meaning of Working Through the Past", in Critical Models: Interventions and Catchwords; ed. Lydia Goher, New Yorrk: Columbia University Press, 2005, 90 .

ADORNO, Theodor W. (ed.). The Authoritarian Personality. New York: Harper, 1950.

AGAMBEN, Giorgio. The Kingdom and the Glory: For a Theological Genealogy of Economy and Government. Stanford: Stanford University Press, 2011.

ALBRIGHT, Madeleine. “Fascism: A Warning” in New York: Harper, 2018.

\footnotetext{
${ }^{24}$ A hipótese de que Macron encarnaria o populismo neoliberal é examinado por Eric Fassin (2017).

Revista de Estudos e Pesquisas sobre as Américas V.13 N.2 2019 ISSN: 1984-1639
} 
ALI, Tarik. The extreme Center: A Warning, London: Verso, 2015.

ANDERSON, Benedict. Imagined Communities. London: Verso, 1983.

BROWN, Wendy. Undoing the Demos: Neoliberalism's Stealth Revolution, New York:Zone, 2015.

CAMUS, Jean-Yves and LEBOURG, Nicolas. Les droites extrêmes en Europe. Paris: Seuil, 2015

CLARK, Christopher. The Sleepwalkers: How Europe went to War in 1914. London: Allen Lane, 2012.

D’ARCAIS, Paolo Flores. "Anatomy of Berlusconismo" in New Left Review 68, 2011, 121 40.

D'ERAMO, Marco. "Populism and the new Oligarchy" in New Left Review 82, 2013, 5-28. "They, the People" in New Left Review 103, 2017, 135.

DE GRAZIA, Victoria. How Fascism Ruled Women. Berkeley: University of California Press, 1993.

DE LA TORRE, Carlos. "Left-Wing Populism: Inclusion and Authoritarianism in Venezuela, Bolivia and Ecuador" in The Brown Journal of World Affairs 23:1, 2016, 61-76.

DOSSE, François. Le philosophe et le Président. Paris: Stock, 2017.

DOUTHAT, Ross. “Is Donald Trump a Fascist?” in New York Times, 3 December 2015.

ESPOSITO, Roberto. Categories of the Impolitical. New York: Fordham University Press, 2015.

FASSIN, Eric. Populisme: Le grand ressentiment. Paris: Textuel, 2017.

FINCHELSTEIN, Federico. Transatlantic Fascism: ideology, violence, and the Sacred in Argentina and Italy, 1919-1945. Durham: Duke University Press, 2010. $251,101$.

From Fascism to Populism in History, Berkeley, University of California, 2017, 98,

GIBELLI, Antonio. Berlusconi passato alla storia: L'Italia nell'era della democrazia autoritaria. Rome: Donzelli, 2011.

HABERMAS, Jürgen. The Structural Transformation of the Public Sphere: Inquiry into a Category of Bourgeois Society. Cambridge, UK: Polity Press, 1991.

Revista de Estudos e Pesquisas sobre as Américas V.13 N.2 2019 ISSN: 1984-1639 
IGOUNET, Valerie. Le Front National de 1972 à nos jours: Le parti, les hommes, les idées, Paris: Seuil, 2014.

JUDT, Tony. Postwar: a history of Europe since 1945. London, Penguin Books, 2005, 157.

KAGAN, Robert. "This Is How Fascism Comes to America” in Washington Post, 18 May 2016.

KAZIN, Michael. The Populist Persuasion: An American History, Ithaca, NY: Cornell University Press, 1998.

KOONZ, Claudia. Mothers in the Fatherland: Women, the Family, and Nazi Politics, New York: St. Martin Press, 1987.

KOSELLECK, Reihart. "Social History and Conceptual History" in PRESNER, Todd Samuel (ed.). The Practice of conceptual History: Timing History, Spacing Concepts. Stanford: Stanford University Press, 2002.

LE BON, Gustave. The Crowd: A Study of the Popular Mind. Mineola, NY: Dover Publications, 2002.

MANN, Thomas. Reflections of a Nonpolitical Man. ed. Walter D. Morris. New York: Frederick Ungar, 1983.

MOSSE, George L.. The Image of Man: The Invention of Modern Masculinity. New York: Oxford University Press, 1998.

2000 .

The Fascist Revolution: Toward a General Theory of Fascism. New York: H. Fertig,

MÜLLER, Jean Werner, What is Populism? Philadelphia: University of Pennsylvania Press, 2016.

PASOLINI, Pier Paolo. Scritti corsari. ed. Alfonso Berardinelli. Milan: Garzanti, 2008.

RANCIÉRE, Jacques. Hatred of Democracy. London: Verso, 2006.

RENZI, Valerio. La politica della ruspa: La Lega di Salvini e le nuove destre europee. Rome: Edizioni Alegre, 2015.

REVELLI, Marco. Populismo 2.0. Turin: Einaudi, 2017.

RIOUX, Jean-Pierre (ed.). Les populismes. Paris: Perrin, 2007.

ROBCIS, Camille. "Catholics, the "Theory of Gender," and the Turn to the Human in France: A New Dreyfus Affair?" in The Journal of Modern History 87, 2015, 893-923. 
ROSANVAllON, Pierre. Counter-Democracy: Politics in an Age of Distrust, Cambridge: Cambridge University Press, 2008.

SCHMITT, Carl. Political Theology: Four Chapters on the Concept of Sovereignty. ed. George Schwab, Chicago: Chicago University Press, 2006.

Press, 2007.

The Concept of the Political, ed. George Schwab, Chicago: University of Chicago

STERNHELL, Zeev. La Droite révolutionnaire 1885-1914: aux origins du fascisme. Paris: Gallimard, 1997.

SHATZ, Adam. 'Wrecking Ball' in London Review of Books, 7 September 2017, 17.

WATKINS, Susan. “The Political State of the Union" in New Left Review 90, 2014, 2-25.

VENTURI, Franco. Roots of Revolution. New York:Grosset and Dunlap, 1966.

ZANATTA, Loris. El Populismo. Buenos Aires: Katz Editores, 2013.

ZEMMOUR, Éric. Le suicide français. Paris: Albin Michel, 2014. 